\title{
Editorial \\ The changing face of groupwork with offenders 1991-2013
}

This is the second occasion that the journal Groupwork has published a special issue on Groupwork with Offenders, the last being in 1991 (Volume 4, Number 3) although in the intervening 22 years there has been a smattering of articles addressing the challenges of groupwork in a criminal justice context. While the last special issue drew in

a very positive response and the constraints of space meant that we had some difficult decisions to make about what to include and what to omit (Brown and Caddick, 1991, p.196)

and, in the event, dictated a decision to focus on groupwork in a Probation context (ibid), the present editor found himself confronting a very different world. Out of six expressions of interest, only two were Probation based - and neither of these, despite the provision of encouragement and support to the potential authors, as expressed in the values of this journal, developed to fruition.

Of the four articles which have made it, metaphorically, to the typesetter's bench, three have academic origins, two are set in prisons and another in a non Probation community setting. None would be seen as located in the mainstream of current Probation practice. While, as I will come to describe later, all present interesting, cogently argued and thought-provoking angles and insights on the possibilities, constraints and challenges in groupwork with offenders, as a collection they suggest that there has been something broader taking place around the discipline and the service over the intervening years, which prima facie merits having a look at. What has been happening to groupwork in the Probation service? In tandem, what has been happening to the service itself?

In 1991, the editors identified an overriding issue - whether emerging policy expectations (Home Office, 1988) that groups will be a vehicle 
for controlling offenders and changing their behaviour, and professional expectations that groups have a primary function to be a vehicle for the empowerment of their members individually and collectively, (Mullender \& Ward, 1991) are compatible (Brown \& Caddick, 1991: 196)? In answer, in an article in the 1991 Special Issue, Senior vividly describes and explains the development in the 1980s

of offence specific practice .... decreasing appreciation by practitioners of the dynamics of the groupwork process and a concentration on the task in hand rather than process. Put at its crudest the groupworker had to have a stock of exercises on the shelf, get them down and do them. (Senior 1991, p.287).

This approach had emerged in the late 1980s as a more promising approach to intractable problems of offending and recidivism (e.g. Lipsey, 1989) and as a core element of official prescriptions for remediation and control of offenders (Criminal Justice Act, 1991).

Certainly this approach produced some high quality training materials. However, without the skills to use the group process appropriately and sensitivity to injustice and oppression (Mullender \& Ward, 1991), opportunities for personal development, for learning about living and working together, and for tackling issues of lack of opportunity and exclusion lying in the wider worlds of group members, would inevitably be missed and crucial work left undone (Senior, 1991, p.287). Such an approach gave workers and group members something to do rather than something to talk about (Blagg \& Smith, 1989, p.111) - or, indeed, act upon.

In 1998 the present editor had come to ask "Where had all the groupwork gone?' (Ward, 1998). He observed that the 1980s and 1990s had seen tremendous changes in the vision and practice of social work as a result of pressures from different directions. In some respects, the forces were in conflict, but, in sum, they had had the effect of putting social work on to a very different footing from the helping and welfare principles that had and, to a large extent, continued to dominate the discourse of the profession and its associated academy and training. The pressures included the drive towards specialisation, confirmed in the dismemberment of the unified local authority Social Services Departments, the emergence of legal and statutory frameworks as paramount concerns, changes and separation in the education and 
training of social workers and probation officers, the impact of 'new managerialism' - all framed within the ascendency of the Thatcherite neo-liberal discourse stressing individualism, competition, 'no excuses' and personal responsibility, and a down-grading of the significance of 'society', that is of social, environmental, and economic factors as influences in people's life conditions and behaviour. This list is neither complete nor exclusive, but provides the context within which an identifiably different groupwork came into position.

In Probation, it was to be found particularly in cognitive-behavioural work with offenders. In some cases, for example in so-called 'What Works' practice with offenders (McGuire, 1995; Chapman \& Hough, 1998; Underdown, 1998), the guiding texts simply pass over groupwork knowledge and skills. There is a close link with a political agenda and managerial strategies to reposition the Probation Service within the criminal justice system as a 'community corrections' agency, narrowing its vision to the oversight and management of the individuals charged to it.

As far as groupwork goes, what we come to find are groups that are predominantly 'one-to-one treatment with the rest of the members acting as bystanders'. In Konopka's (1990) view (cited by Kurland \& Salmon, 1993, p.8), such groups are boring, suppressing and run by people who must maintain control. Process is used to enhance conformity; dissenters may be humiliated; revealing is required, with punishment if refused. Although Kurland and Salmon are writing about the American scene, British writers have made similar observations. Brown (1994, p.45) noted that the trend towards groups that are increasingly taskoriented, with decreasing emphasis being paid to process,

reduces groupwork ... to a rather sterile exercise in which group members receive packaged group programmes of limited usefulness, making no real impact on them as unique individuals often caught up in oppressive social conditions of poverty.

Exemplfying this, Malcolm Cowburn (a coauthor of one of the papers in the current special issue) and Panna Modi (1995) critically evaluated approaches, predominantly based in groups, to working with male sex abusers. They saw in the then, and still, prevalent cognitive-behavioural programmes and, in particular, in the practice 
of individual confrontation, oppressive Eurocentric and heterosexist assumptions, grounded in conformity and obedience, which, ironically, are potentially dangerous in reinforcing abusers' minimalist views of their own responsibility and the harm their actions have caused. Effective practice, they argued:

needs to help to develop a person's positive sense of identity as a firm base from which knowledge, skills and understanding about offending behaviour can be brought together to avoid re-offending ... it needs to be experienced within a context that is not oppressive (Cowburn \& Modi, 1995, pp.204-205).

Groupwork may have become unfashionable precisely because it acknowledges that groups develop a life of their own over which the worker cannot ever have complete control. In a group, the agenda is likely to be holistic. Group members will raise what is important and significant to them, no matter what 'ground rules' and boundaries have been set. Such free-flowing characteristics are out of kilter with a climate which emphasises, discipline, individual responsibility and, at an organisation level, preset objectives and audited outcomes. The outcome has been many projects and workers for whom the democratic, collective and empowering ideals that are embedded in real groupwork are unfamiliar and regarded with suspicion (Drakeford, 1994, p.237).

As the years have passed, regretfully these trends have been strengthened and consolidated as neo-liberalism appears to have assumed unchallengeable ascendancy. In 1997, in collaboration with my late colleague Roy Bailey, I reviewed the empirical basis for the What Works movement which, by that point, had gained intellectual and operational ascendancy in the work of the Probation Service and was dominating Probation discourse (Bailey \& Ward, 1997). We concluded that, while What Works had some empirical underpinning, despite cautionary notes struck by some writers, an effect had been to marginalize other approaches more in tune with probation and social work values, despite research evidence of their efficacy. We detected a close link with the aforesaid political agenda and managerial strategies to reposition the Probation Service within the criminal justice system.

Ten years further on, in 2008 and continuing, in a further review 
(Ward, 2008), I discovered that the mantra for Probation practice had become Offender Management underpinned by the Offender Management Model (OMM). In the language of the National Offender Management Service (NOMS), which was now the central government department managing Probation and, also, prisons, OMM provides a multi-layered and comprehensive framework for managing offenders (National Offender Management Service, 2006).

The notion of Offender Management emerged from, and became an established part of the criminal justice vocabulary, as a result of Lord Carter's review of the correctional services in England and Wales (Carter, 2004). Pitts (2007), in a highly critical review of What Works, but appertaining equally to the OMM, sees the nature of the contemporary relationship between government and the criminological establishment being one in which the expected and logical interaction between criminological theory and criminal justice policy have, more often than not ,come to be reversed: theory and research being taken up selectively as post factum rationales for preordained policy.

Now the principle [sic] function of much criminological research ... was to put empirical flesh on the bones of what had already been sold to the public as evidence-led policy (Pitts, 2007, p.15).

What we can see within the genesis of the OMM is a politically driven policy initiative being transmuted into frameworks and methodologies for implementation, which are successively focused on organizational structure, on the management of practitioners and on face-to-face practice with offenders. Within a contemporary penal agenda which stresses retribution and punitive control, fuelled by 'punitive-populism' (Burnett et al., 2007, p.228), earlier work on Probation case management, for example, Holt $(2000$,) was incorporated to provide an operational framework, with learning of the so-called 'key messages' from the service's implementation of What Works programmes (Raynor \& Maguire, 2006, p.27) as the substance for face-to-face practice. To some extent these home-grown elements of the model may also have had the function of providing a 'conceptual deodorant' (Ward \& Mullender, 1991) to obscure aspects of the national penal agenda embedded in the model which probation officers would otherwise find unpalatable.

Groupwork Vol. 23(3), 2013, pp.3-14. DOI: 10.1921/6601230303 
It is possible to detect that similar trajectories had taken place earlier in the evolution of What Works to become a Probation staple and, in the wider public sphere, in the rhetorics and practices surrounding modernization and, even, user empowerment (Mullender, Ward, \& Fleming, 2013, Chapter 2). Again, the collective and empowering ideals that are embedded in real groupwork are discounted and, hence, become unfamiliar to practitioners and likely to be regarded with suspicion. Thus, what was identified in 1991 as an incipient trend had become a head-long rush into practices which are clearly not compatible with orientations that state that groups have a primary function to be a vehicle for the empowerment of their members (Brown \& Caddick, 1991). This feels particularly tragic when one of the strongest examples of Probation practice impacting on reoffending, rehabilitation and, consequently, public protection is grounded in empowerment focused groupwork (Mullender, Ward, \& Fleming, 2013, Chapter 6).

So, to come right up to date, in 2013 we find a Probation Service about to be dismembered. Under the Transforming Rehabilitation 'roadmap' (Ministry of Justice, 2013) the government will legislate so that, in its own language:

- A new public sector National Probation Service will be created, working to protect the public and building upon the expertise and professionalism which are already in place.

- For the first time in recent history, every offender released from custody will receive statutory supervision and rehabilitation in the community. We are legislating to extend this statutory supervision and rehabilitation to all 50,000 of the most prolific group of offenders - those sentenced to less than 12 months in custody.

- A nationwide 'through the prison gate' resettlement service will be put in place, meaning most offenders are given continuous support by one provider from custody into the community. We will support this by ensuring that most offenders are held in a prison designated to their area for at least three months before release.

- The market will be opened up to a diverse range of new rehabilitation providers, so that we get the best out of the public, voluntary and private sectors, at the local as well as national level.

- New payment incentives for market providers to focus relentlessly on reforming offenders will be introduced, giving providers flexibility to 
do what works and freedom from bureaucracy, but only paying them in full for real reductions in reoffending.

The aspiration to provide a resettlement service for short term prisoners, a group whose reoffending rate is over $60 \%$ within one year of release, is certainly to be applauded. However, the means must be a cause for concern. The Probation Service is to be split in half. A new national service, run from Whitehall, will undertake advisory work to the courts and the management of offenders assessed as posing a high risk of harm to the public. The other part is to be incorporated into 21 regional Community Rehabilitation Companies (CRCs). These will take on the supervision in the community of 'low risk' offenders, substantially through Community Punishment, otherwise known as Unpaid Work and, in some jurisdictions, as Community Service. The CRCs will also provide the much trumpeted new resettlement service for short term prisoners. CRCs are to be offered, through a market-based competition, to not-for profit and commercial organizations. Probation officers at the time of writing, December 2013, are being allocated to their new employers and compulsorily transferred. Neo liberal values have come to penetrate deeply.

On the face of it, this practice and policy backdrop would hardly seem to be favourable for real groupwork. However, even within such a punitive and neo liberal policy climate, the persistence of high levels of recidivism is forcing some reconsideration of what might be more effective than the erstwhile preoccupation on pro forma assessments, structured individual supervision and pre-defined programmes, as defined by the Offender Management Model (Knight, 2007; Rex, 2010; Ministry of Justice, 2011). An approach that has gained some traction, advocated in particular by Fergus McNeill from the Glasgow School of Social Work, is one that is based on a 'desistance paradigm' (Burnett $\&$ McNeill, 2005; McNeill et al., 2005; McNeill, 2006, 2007).

Desistance theory identifies a number of interacting features as influential in the achievement of 'desistance' which, in this context, basically means stopping offending. These features include an offender's self-assessment of it being worth staying out of crime and the development of the capacity to say 'no', the role of a committed and helpful professional, and improvements in the offender's community, social and personal circumstances and relationships. Desistance, as 
McNeill explains it, involves not just the decision of an individual but also a set of social processes activated within significant social institutions and in collective environments, such as work, education, the family, community engagement and peer relations. To facilitate such engagement and the possibility of 'desistance', Farrall (2007) argues that the ways these institutions and environments operate, and how they might be harnessed, needs to be understood and acted upon.

Groupwork shares with the desistance model recognition of the importance and nature of the practitioner-participant relationship, particularly, in supporting people to establish their own understandings of their problems and to make their own decisions on pathways towards solving them. For those with optimistic inclinations, the desistance model provides an important and encouraging counterbalance to contemporary preoccupations with 'community punishments' and the 'management' of offenders in the community - and an opening for real groupwork. So, maybe, all is not lost.

This is the context within which I invite readers to consider the papers in this special edition. As noted earlier, none are derived from 'mainstream' Probation practice but all do exhibit features of recognisably real groupwork providing, as Senior (ibid) put it 20 or so years ago, opportunities for personal development, for learning about living and working together, and for tackling issues of lack of opportunity and exclusion lying in the wider worlds of group members. Indeed, there is a touch, at least, of 'empowerment' within each of them, even though two are set within that least unfavourable of settings, prison, and another addresses with work with sex offenders.

Taking the articles in alphabetical order of their first authors, first of all, Claire Bellamy and Aileen Watson discuss the use of Circles of Support and Responsibility (COSA) with sex offenders. The COSA model uses a group of volunteers to form a 'Circle' around an offender who is viewed as being very much part of the group. The authors examine the expectations and opinions of both offenders and volunteers to make some assessment of how well this non-traditional form of group work operates. Their findings present an almost entirely positive picture of COSA from the perspective of both the volunteers and the offenders. The 
key factors in relation to successful group working were identified as a diverse mixture of group members to offer different perspectives and a sense of trust, openness and equality between all the Circle members. They argue that effective rehabilitative work needs to take a more holistic, strengths based approach that looks forward at the possibility of desistance rather than focusing 'backwards' on the offence and the deficits of the offender.

In their paper, Malcolm Cowburn and Victoria Lavis describe and review their experiences in setting up and running an advisory group of prisoners as a core element of a research project in a maximum-security prison in England. The research project used the method known as Appreciative Inquiry to explore the experiences of minority group prisoners and the strategies of the prison to accommodate the complex needs of these groups. The paper considers the groupwork processes at play in establishing an effective participant voice in a prison-based project. It considers the contribution of the group to developing a research strategy that engaged prisoners in the research and reflects on the nature of 'participative research' in general and the issues involved in undertaking such research within a high-security prison environment.

From across the 'pond', in another prison-focussed article, Tina Jordan describes a research project investigating health literacy among African Americans in the particular context of the execution of 'advance directives', more commonly known in the UK as Living Wills, by African American prisoners, many of whom are subject to sentences such that they may become seriously ill and/or die while in prison. Although the detailed presentation of her research makes for a rather dense paper, Jordan shows vividly, through the lens of health literacy, the historical and ongoing oppressions confronting African Americans, and prisoners in particular, and the responsibilities and tasks that rest upon 'corrections', health and social welfare professionals. En route, Jordan demonstrates, from within her research methodology, how group-based intervention can empower such prisoners to develop greater knowledge, understanding and capacity in the execution of an advance directive to press forward on one aspect of their fundamental human rights at least.

In the fourth article, Pete Wallis, Lean Mclellan, Kathryn Clothier and Jenny Malpass of the Oxfordshire Youth Offending Service describe and discuss, two groupwork programmes. The first is the Assault Awareness Course, which is a victim empathy programme for young people whose 
crime involved violence, and the second is the New Drivers' Initiative for young people charged with vehicle offences. Both programmes are standardised and pre-structured, and could be delivered individually. However, the authors show how delivering them as groupwork makes them particularly powerful:

The young people learn about communicating honestly and with respect. A talking piece encourages participation and active listening, enabling group members to hear and reflect on one another's experiences and perspectives. Groups bring a particular dynamic. .... challenging neutralisation and in promoting responsibility .... Owning up to one's responsibility for causing harm feels shameful and the group becomes a supportive environment where participants work with one another in finding positive ways to feel better by addressing the harm they caused.

I commend these papers to the readership of this journal. Optimistically, they show that real groupwork is alive and well in work with offenders, be it indirectly though participatory research or directly among volunteers and some practitioners. In common, all subscribe to the tenet that groupwork is about working with, not on! But .. what about Probation?

Dave Ward

December 2013

\section{References}

Bailey, R. and Ward, D. (1997) Probation Research. What Works: Who Cares? Issues in Social Work Education, 17, 2, 3-16

Blagg, H. and Smith, D. (1989) Crime, Penal Policy and Social Work, London: Longman

Brown, A. (1994) Groupwork in Britain. in C. Hanvey and T. Philpot (Eds.) Practising Social Work, London: Routledge

Brown, A. and Caddick, B. (1991) Editorial. Groupwork, 4, 3, 195-196

Burnett, R., and McNeill, F. (2005) The place of the officer-offender relationship in assisting offenders to desist from crime. Probation Journal, 52, 3, 221-242 
Burnett, R., Baker, K. and Roberts, C. (2007) 'Assessment, supervision and intervention: fundamental practice in probation', in L. Gelsthorpe and R. Morgan (Eds., Handbook of Probation, Cullompton: Willan

Carter, P. (2004) Managing Offenders, Reducing Crime. London, Home Office

Chapman, T . and Hough, M. (1998) Evidence Based Practice: A Guide to Effective Practice, London: Home Office

Cowburn, M. and Modi, P. (1995) Justice in an unjust context: Implications for working with adult male sex offenders. in D. Ward and M. Lacey (Eds.) Probation: Working for Justice, London: Whiting and Birch

Drakeford, M. (1994) Groupwork for parents of young people in trouble. Groupwork, 7, 3, 236-247

Farrall, S. (2007) Desistance. in R. Canton and D. Hancock (Eds.) Dictionary of Probation and Offender Management. Cullompton: Willan

HM Government (1991) Criminal Justice Act 1991. London: HMSO

Holt, P. (2000) Case management: Context for supervision. Community and Criminal Justice Monograph 2, Leicester: De Montfort University

Home Office (1988)Punishment, Custody and the Community. London: HMSO

Knight, C. (2007) The re-emergence of the importance of the 'relationship' within community and criminal justice practice. British Journal of Community Justice 5, 3, 1-4

Konopka, G. (1990) Past/present issues in group work with the emotionally disabled: Part II, thirty-five years of group work in psychiatric settings. Social Work with Groups, 13, 1, 13-15

Kurland, R. and Salmon, R. (1993) Groupwork versus casework in a group. Groupwork, 6 (1, 5-16

Lipsey, M.W. (1989). The efficacy of intervention for juvenile delinquency: Results from 400 studies. Paper presented at the annual meeting of the American Society of Criminology. Reno, NV

McGuire, J. (Ed.) (1995) What Works: Reducing reoffending: Guidelines from research and practice. Oxford: John Wiley

McNeill, F. (2006) A desistance paradigm for offender management. Criminology and Criminal Justice, 6, 1, 39-62

McNeill, F. (2007) Desistance. in R. Canton, and D. Hancock (Eds.) Dictionary of Probation and Offender Management. Cullompton: Willan

McNeill, F., Batchelor, S., Burnett, R. and Knox, J. (2005) 21st Century Social Work. Reducing Re-offending: Key Practice Skills. Edinburgh: Scottish Executive Ministry of Justice (2011) National Standards for the Management of Offenders, London: Ministry of Justice

Groupwork Vol. 23(3), 2013, pp.3-14. DOI: 10.1921/6601230303 
Ministry of Justice (2013) Transforming Rehabilitation, http://www.justice.gov. uk/transforming-rehabilitation, accessed 27/11/2013

Mullender, A. \& Ward, D (1991) Self-Directed Groupwork: Users take action for empowerment. London: Whiting and Birch

Mullender, A., Ward, D., Fleming, J. (2013) Empowerment in Action: Self-directed groupwork. Basingstoke: Palgrave

National Offender Management Service (2006) The NOMS Offender Management Model. London: Home Office

Pitts, J. (2007) Who Cares What Works? Youth and Policy, 95, Spring, 5-24

Raynor, P. and Maguire, M. (2006) 'End-to-end or end in tears': Prospects for the effectiveness of the National Offender Management Model. in M. Hough, R. Allen and U. Padel (Eds) Reshaping Probation and Prisons, The new offender management framework, Bristol: The Policy Press

Rex, S. (2010) Offender Engagement Programme. East of England: National Offender Management Service

Senior, P. (1991) Groupwork in the Probation Service: Care or control in the 1990s. Groupwork, 4, 3, 284-295

Underdown, A. (1998) Strategies for Effective Offender Supervision: Report of the HMIP What Works Project. HM Inspectorate of Probation, London: Home Office

Ward, D. (1998) Groupwork. in R. Adams, L. Dominelli, and M.Payne (Eds.) Social Work: Themes, issues and critical debates. London: Macmillan

Ward, D. (2008) What Works in Probation Offender Management: evidence for a new direction? British Journal of Social Work, 38, 2, 395-405

Ward, D. and Mullender, A. (1991) Empowerment and oppression: The indissoluble link. Critical Social Policy, 32, 21-30 